\title{
Hepatitis A: the burden among Latino children in California
}

\author{
David E. Hayes-Bautista, PhD,(1) Paul Hsu, MSP,(2) Aidé Pérez, BS, (3) \\ Lucette Sosa, BS, ${ }^{(3)}$ Cristina Gamboa, BS.(1)
}

\section{Hayes-Bautista DE, Hsu P, Pérez A, Sosa L, Gamboa C. Hepatitis A: the burden among Latino children in California.} Salud Publica Mex 2005;47:396-40I.

\begin{abstract}
Objective.To determine the prevalence of Hepatitis A within subpopulations of southern California counties. Material and Methods.Age and race/ethnic-specific hepatitis A rates were derived from the California Department of Health Services Surveillance and Statistics Section for 1996-200I and from demographic data of the California Department of Finance. Results. 2.3 million Latino children (aged 0-14 years) in five southern California counties had a rate of $3 \mathrm{I}$.I cases per 100000 , five times higher than the non-Hispanic white rate. Conclusion. The CDC Advisory Committee on Immunization Practices recommends routine vaccination for children with "very high" rates of hepatitis A. The annual prevalence of hepatitis A in California, especially in southern California, met the CDC's "very high" definition, therefore Latino children in these counties should be considered for routine childhood hepatitis $A$ vaccination. As health has no borders, this issue should be addressed by the public health services of both, the United States' and Mexico's public health services.
\end{abstract}

Key words: hepatitis A; vaccination; Latino; United States
Hayes-Bautista DE, Hsu P, Pérez A, Sosa L, Gamboa C. La hepatitis A: impacto entre los niños latinos californianos.

Salud Publica Mex 2005;47:396-40I.

\section{Resumen}

Objetivo. Determinar la tasa de prevalencia de la hepatitis A entre ciertos grupos de población de los condados del sur de California. Material y métodos. Se calcularon las tasas de hepatitis A por edad y raza/etnia utilizando los datos de los archivos del Centro de Servicios de Salud y Vigilancia de California, y los denominadores demográficos del ciclo 1996-200I de la Sección de Estadísticas del Departamento de Finanzas de California. Resultados. Los $2.3 \mathrm{mi}-$ llones de niños latinos (de 0 a 14 años) de cinco condados del sur de California presentaron una tasa de 31 .I casos por cada 100000 niños, lo que muestra que es cinco veces más alta que la tasa anglosajona. Conclusión. El Comité Consejero de Prácticas de Inmunización del CDC recomienda vacunar rutinariamente a los niños con índices "muy altos" de hepatitis A. La frecuencia anual de hepatitis A, especialmente en el sur de California, alcanzó el índice "muy alto" de acuerdo con lo establecido por el CDC; por lo tanto, debería considerarse a los niños latinos de estos condados para la administración rutinaria de vacunas contra la hepatitis A. Como la salud no tiene fronteras, este problema debería tomarse en cuenta por los servicios de la salud pública de ambos países, México y Estados Unidos.

Palabras clave: hepatitis A, vacuna, latino; Estados Unidos

(I) Center for the Study of Latino Health and Culture, Department of General Internal Medicine and Health Services Research. UCLA School of Medicine, Los Angeles, California.

(2) Department of Epidemiology, UCLA School of Public Health, Los Angeles, California.

(3) MS II, University of Chicago at Illinois, Chicago, Illinois.

Received on: January 3, 2005 - Accepted on: August 25, 2005

Address reprint requests to: D. E. Hayes-Bautista. Center for the Study of Latino Health and Culture. 924 Westwood Blvd., Suite 730. Los Angeles, CA 90024.

E-mail: dhayesb@ucla.edu 
$\mathrm{H}$ epatitis A is the most common type of hepatitis reported in the United States and, despite licensure of a vaccine in $1995,{ }^{1,2}$ is still among the most commonly reported vaccine-preventable diseases. ${ }^{3,4}$ The highest rates occur in children younger than 15 years of age. ${ }^{5}$ From 1980 to 1999, the incidence of hepatitis A infections was 18.7 and 12.5 cases per 100000 in the $5-9$ years age group and 10-14 years age group, respectively, compared with 10.5 cases per 100000 across all age groups. ${ }^{6}$ Rates also vary by race and ethnicity, with the highest U.S. rates noted among Native American/ Alaskan natives and Latinos. ${ }^{7}$ These ethnic differences probably reflect correlations between race/ethnicity and factors such as socioeconomic levels and frequent contact with persons from countries where the disease is endemic. ${ }^{1}$

Unlike hepatitis B and hepatitis C, which occur primarily in high-risk individuals, hepatitis A prevalence varies regionally and tends to manifest in community-wide epidemics. ${ }^{2,3,5}$ Children provide a critical transmission link, largely because they are more likely than adults to have asymptomatic or unrecognized hepatitis A illness. ${ }^{5-8}$ Because of these related factors, the Centers for Disease Control and Prevention (CDC) Advisory Committee on Immunization Practices (ACIP) recommends routine vaccination against hepatitis A for children who live in states, counties, or communities where the average annual rate between 1987 and 1997 was 20 or more cases per 100000 population. ${ }^{1}$ Because the incidence of hepatitis A among the susceptible population ("force of infection") declines with age, routine childhood vaccination should induce a strong "herd immunity" effect that would substantially lower incidence in non-immunized children and adults. ${ }^{1}$ During the ten-year period under study, ACIP identified 11 states, including California, that had "very high" rates of hepatitis A (20 or more cases per 100 000). The other states were Arizona, Alaska, Oregon, New Mexico, Utah, Washington, Oklahoma, South Dakota, Idaho, and Nevada. ${ }^{1}$ States with rates of 10.0 to 19.9 cases per 100000 were considered to have "high" rates. States with rates less than 10.0 per 100000 were considered "low" rates.

Because of their large Latino populations, many California communities are at even greater risk for hepatitis A than the statewide rate would indicate. In southern California, hepatitis A is endemic and occurs at a significantly higher rate in the Latino population compared to other groups. ${ }^{9}$ The objective of this study was to determine hepatitis A prevalence within subpopulations of five large southern California counties.

\section{Material and Methods}

\section{Calculation of hepatitis A rates}

Hepatitis A rates were calculated for the state of California and its five largest southern counties (Los Angeles, Orange, Riverside, San Bernardino, and San Diego). The number of hepatitis A cases for California and the southern California counties were obtained from the state's Department of Health Services; ${ }^{*}$ population estimates for the state and the counties were obtained from the California Department of Finance. ${ }^{10}$ Local health departments in the state of California are responsible for detecting and reporting communicable disease to the California Department of Health Services. Likewise, local departments are responsible for confirming reported cases. Generally, the positive diagnosis of acute hepatitis A requires having a positive laboratory test for the IgM antibody to HAV, which can indicate recent infection. A case meets the clinical definition if it occurs in a person who has an epidemiologic link to a person who has laboratory-confirmed hepatitis A (i.e., living in the same household or having sexual contact of an infected person during the 15 to 50 days before the onset of symptoms). ${ }^{11}$ Both sets of figures were stratified by ethnicity (Asian/Pacific Islander, African-American, Latino, nonHispanic white, and Native American), by sex, and by age. Cases with unknown gender or ethnicity or with ethnicity coded as "other" were excluded from the calculations, as were Native Americans, who represented a very small number of reported cases.

Average annual hepatitis A rates per 100000 for the interval 1996-2001 were calculated by dividing the total number of cases for this period by the total population for the same period and multiplying by 100000 . The relative risk of hepatitis A for Latino children compared with non-Hispanic white children 0 to 14 years of age was calculated for each target county by dividing the hepatitis A rate in Latino children by that in non-Hispanic white children.

\section{Calculation of Nativity}

The nativity of children in California was determined from the Census Bureau's Public Use Microdata Sample (PUMS). ${ }^{12}$ Data were obtained for 2000.

\footnotetext{
* Personal communication from Stanley R. Bissell, Acting Chief, Surveillance and Statistics Section, Infectious Disease Branch, Division of Communicable Disease Control, California Department
} of Health Services (2/4/2004) 


\section{Results}

\section{Demographics of five counties}

The demographics of the southern California counties, based on age and race/ethnicity, are shown in table I. For 2001, the 4.6 million Latinos in Los Angeles County represented $46.1 \%$ of the county's total population of approximately 10 million, but accounted for higher percentages of the younger age groups. Of children 0 to 4 years of age, $64.6 \%$ were Latinos, $17.2 \%$ were nonHispanic whites, $8.0 \%$ were African-Americans, and $10.1 \%$ were Asian/Pacific Islanders. Similar trends were observed in Orange, Riverside, San Bernardino, and San Diego counties, in which Latinos comprised between a quarter and a third of the overall populations, with higher percentages among children and adolescents. Especially in the younger age groups (0-4, 5-9), Latinos represented either the majority or the plurality of the population in every county (see table I). Moreover, the percentages of Latino population in the five counties are projected to increase through the year 2020.

Hepatitis A is not imported by large numbers of immigrant Latino children. In fact, the vast majority of Latino children (age 0 to 14 years) are born in the United States. In 2000, 88.3\% of the 3.5 million Latino children 0 to 14 years in California were U.S.-born. Likewise, a pattern of more U.S.-born than immigrant children is observed in each of the southern California counties (see table II).

\section{Rates of hepatitis A in southern California}

For the six-year period under study, the average annual hepatitis A rate for Latino children (0-14 years of age) in the southern California counties was 31.13 per 100000 -more than five times as high as the second highest rate, of 5.83 for non-Hispanic white children,
Table I

LATINO POPULATION AS PERCENT

OF TOTAL POPULATION AND TOTAL AGE GROUP

by county in California, 200 I

\begin{tabular}{cccccc} 
& \multicolumn{6}{c}{ County } \\
\cline { 2 - 6 } & Los Angeles & Orange & Riverside San & & \\
& $\approx 9.9$ & $\approx 2.9$ & $\approx 1.6$ & $\approx 1.8$ & $\approx 3.0$ \\
Total population & million & million & million & million & million
\end{tabular}

\% Latino within Age Group

\begin{tabular}{llllll}
$0-4$ yrs & 64.6 & 49.0 & 50.0 & 50.4 & 40.4 \\
\hline $5-9$ yrs & 62.7 & 46.4 & 45.0 & 44.4 & 39.9 \\
\hline I0- I4 yrs & 55.9 & 38.0 & 37.4 & 38.1 & 32.2 \\
\hline I5+ yrs & 41.0 & 25.5 & 26.3 & 29.4 & 21.6 \\
All ages & 46.1 & 30.3 & 30.8 & 33.5 & 25.4 \\
\hline
\end{tabular}

$0-4$ yrs projected

$\begin{array}{llllll}\text { to } 2010 & 70.1 & 53.5 & 54.2 & 55.3 & 43.5\end{array}$

$0-4$ yrs projected

\begin{tabular}{llllll} 
to 2020 & 73.7 & 59.5 & 60.0 & 61.2 & 49.5 \\
\hline
\end{tabular}

Source: California Department of Finance

and about 1.6 times that of the CDC-defined "very high" rate (see figure 1). Yearly relative risks of hepatitis A for Latino children in southern California, when compared to non-Hispanic white children, ranged from 4.50 times higher in 1998 to as high as 7.40 times greater in 1997. From 1996 to 2001, the average risk of contracting hepatitis A was 5.92 times greater in Latino children than in non-Hispanic white children.

\section{Hepatitis A rates in children by county, age, and race/ethnicity}

The nearly 10 million residents of Los Angeles County had yearly hepatitis A rates of 11.13 cases per 100000

Table II

Nativity of latino children age 0-I 4 in southern California, 2000

\begin{tabular}{lcccrr} 
& \multicolumn{5}{c}{ County } \\
\cline { 2 - 6 } & Los Angeles & Orange & Riverside & San Bernardino & San Diego \\
Total Latino Population Age (0-14) & $1315 \quad 117$ & 282797 & 192173 & 233150 & 234959 \\
\hline $\begin{array}{l}\text { \% Latino by Nativity } \\
\text { U.S.- Born }\end{array}$ & 88.3 & 84.2 & 90.4 & & 92.1 \\
\hline Non-U.S.- Born & 11.7 & 15.8 & 9.6 & 7.9 & 88.9 \\
\hline
\end{tabular}

Source: United States Census Bureau 


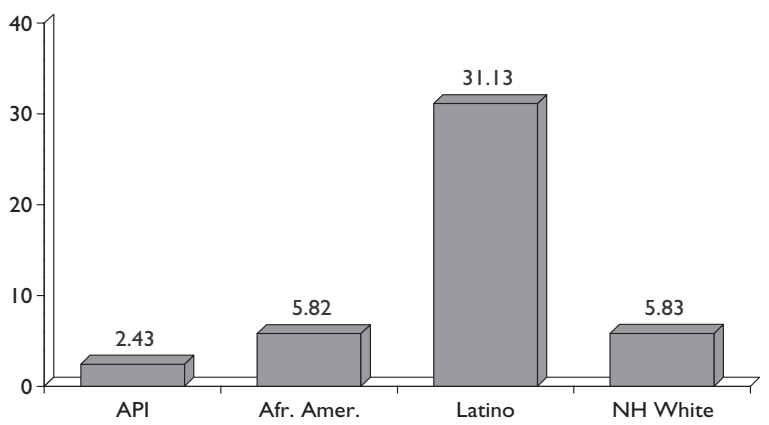

Note: Native Americans/ Alaskan Natives were not included due to small number of cases.

Source: California Department of Health Services

Figure I. Hepatitis a CASES Per I 00000 for Children age 0-14, southern California Counties (Los Angeles, Orange, Riverside, San Bernardino, San DieGO), | 996-200 I

population from 1996 to 2001, placing the county in the ACIP "high" rate category (prevalence between 10 and 20 cases per 100000 ). Overall rates of 10.85, 12.41, and 13.05 also earned San Diego, Riverside, and San Bernardino counties a "high" rating. The overall rate in Orange County was 9.08.

Rates of hepatitis A for Latinos of all ages in Los Angeles County were somewhat higher than in the overall population but still within the "high" rate range (see table III). In children 0 to 14 years of age, moreover, rates were "very high." Prevalence in this age group was approximately 5.5 times higher among Latino children than among non-Hispanic white children.

Similar trends were seen in the remaining four southern California counties. Rates among Latinos of all ages were either "high," as in Orange, San Bernardino, and San Diego counties, or "very high," as seen in Los Angeles and Riverside. These rates tended to exceed considerably those of non-Hispanic whites, African-Americans, and Asian/Pacific Islanders. Moreover, when the 0 to 14 year-old group was examined separately, Latino children in each county were well into the "very high" category. The hepatitis A rate among Latino children in Riverside County, for example, was over six times as high as that among non-Hispanic whites, almost twice as high as for African-Americans, and over three times as high as for Asian/ Pacific Islanders (see table III).
Table III

Yearly hepatitis a CASES PER 100000 IN CHILDREN AGE 0-I 4 YEARS BY RACE/ETHNICITY AND COUNTY in California, I 996-200 I

\begin{tabular}{ccccc} 
& \multicolumn{4}{c}{ Cases/l00,000 Population } \\
\cline { 2 - 5 } $\begin{array}{l}\text { Countyl } \\
\text { Age Group }\end{array}$ & Latino & $\begin{array}{c}\text { Non-Hispanic } \\
\text { White }\end{array}$ & $\begin{array}{c}\text { African } \\
\text { American }\end{array}$ & $\begin{array}{c}\text { Asian/ } \\
\text { Pacific Islander }\end{array}$ \\
$\begin{array}{c}\text { Los Angeles } \\
\text { All ages }\end{array}$ & $15.13^{*}$ & 9.23 & 7.73 & 4.31 \\
\hline 0-14 yrs & $29.40^{\ddagger}$ & 5.34 & 4.65 & 2.19 \\
Orange & & & & \\
All ages & $15.20^{*}$ & 7.03 & 6.92 & 2.87 \\
\hline 0-14 yrs & $32.24^{\ddagger}$ & 3.65 & - & $2.33^{\S}$
\end{tabular}

Riverside

\begin{tabular}{lllrc} 
All ages & $23.86^{\ddagger}$ & 7.43 & 9.99 & 7.58 \\
\hline $0-14$ yrs & $43.49^{\ddagger}$ & 6.87 & $24.34^{\ddagger}$ & $11.89 *$
\end{tabular}

San Bernardino

\begin{tabular}{lllll} 
All ages & $19.97^{*}$ & 9.89 & 6.93 & 5.42 \\
\hline $0-14$ yrs & $31.13^{\ddagger}$ & 9.82 & $8.86^{\S}$ & $7.92^{\S}$
\end{tabular}

San Diego

\begin{tabular}{lllll} 
All ages & $18.27^{*}$ & 8.64 & $10.25^{*}$ & 4.79 \\
\hline $0-14$ yrs & $32.04^{\ddagger}$ & 5.94 & $6.92^{*}$ & $3.28^{\S}$
\end{tabular}

* ACIP "high" rate

‡ ACIP "very high" rate

$\S$ Fewer than 30 cases; data may not be sufficiently robust

Source: California Department of Health Services

\section{Discussion}

In the southern California counties of Los Angeles, Orange, Riverside, San Bernardino, and San Diego, hepatitis A lays a heavy burden on Latino populations, with children suffering higher rates than adults and far higher rates than their non-Latino counterparts.

This problem is not trivial. At 2.5 million in 2000, the population of Latino children (0-14) in just this five-county region is larger than the total population (all age groups, all races/ethnicities) of some states. In fact, six of the remaining 10 states identified by ACIP as having "very high" infection rates have total populations that are less than the number of Latino children in our study region. ${ }^{14}$ Given the projected growth of Latino populations through 2020 within the 
five counties, the potential impact on public health is significant.

Although, by law, each case of hepatitis A treated by a healthcare provider must be reported to health authorities, ${ }^{1}$ this disease is sometimes missed. Some cases are "asymptomatic," in which the classic symptoms -fever, malaise, anorexia, nausea, dark urine, and jaundice- are not apparent or may be misdiagnosed as other viral illnesses, such as influenza or rotavirus infections. ${ }^{5,6}$ The CDC estimates the underreporting of hepatitis A cases to be around 30\%. No studies, to date, have evaluated underreporting among Latinos specifically, but mathematical modeling studies designed to correct for the high incidence of anicteric infection among children, and for the underreporting of clinical cases, indicate that in the general population estimated hepatitis A infections are as much as 10.4 times the number of those actually reported. ${ }^{6}$ Therefore, actual rates among Latino children in the southern California counties combined may have been much higher than the annual rate defined in the present study.

Groups at an increased risk of contracting hepatitis A include persons traveling to countries with high or intermediate endemicity of hepatitis A, food handlers, children and adults at day care centers, schoolage children, health-care institution employees, and workers exposed to sewage. ${ }^{1}$ Among Latino children, low socioeconomic status and overcrowding, as well as frequent contact with travelers from endemic areas (e.g., Mexico, Central America), underlie their high risk of contracting hepatitis A. Likewise, although international travel accounts for less than $10 \%$ of hepatitis A cases, two-thirds of Hispanic children living close to the U.S.-Mexico border, such as those in southern California, reported traveling during the incubation period, principally to Mexico. ${ }^{14}$

National surveillance data indicate that approximately $50 \%$ of hepatitis A infections in the United States occur in persons with no known risk factors. Rather, disease tends to appear in community-wide epidemics that generally originate in high-rate areas but have the potential to spread from one community to another. ${ }^{1,2,3}$ At the national level, despite an overall pattern of slow decline, epidemics of hepatitis A have erupted about every 10 years. ${ }^{3}$ California appears to be at or near the bottom of a 10-year cycle, according to data from the state's Department of Health Services, and thus an upturn in hepatitis A rates may already have begun during early 2000 .

Regardless of the cyclical pattern, however, Latino children consistently are at higher risk for hepatitis A infection and epidemic than non-Hispanic white children are. From 1996 to 2001, while overall preva- lence in California declined, the relative risk of hepatitis A in Latino children remained fairly constant, at nearly five times that in non-Hispanic white coevals. Thus, Latino children would be particularly affected by an epidemic and, as a high-risk population contributing to transmission, including to adults, could play a predominant role in initiating or continuing a cyclic epidemic.

This study has shown a heavy burden of hepatitis A on Latino populations, especially children, in southern California counties. The ACIP recommends routine vaccination of children in areas with "very high" rates (20 or more cases per 100000$)$ and consideration of routine childhood vaccination in areas of "high" rates (between 10 and 20 cases per 100 000). Latino children living in counties that meet the ACIP "very high" definition should become strong candidates for routine hepatitis A vaccination. The availability of the hepatitis A vaccine provides the opportunity to substantially lower disease incidence and potentially eliminate infection. ${ }^{1}$ Yet, a sustained reduction in hepatitis A is unlikely to occur through merely vaccination of selected high-risk groups or short-term programs to control individual community-wide epidemics. To achieve a sustained reduction in national incidence of hepatitis A, mandated and more widespread routine vaccination of children is needed. ${ }^{2}$

In California the burden of infectious disease has significantly increased, and certain communities, such as the Latino population, have experienced a disproportionate burden. ${ }^{15}$ The U.S.-Mexico border area has a combined population of more than 11 million people, many of whom cross the border frequently in either direction to visit family and friends, shop, work, attend school, or seek medical care. ${ }^{16}$ This greater rate of international travel and higher hepatitis A rates affecting the Latino population are a binational issue. Primary care pediatricians and other health care providers treating Latino children who reside in areas where routine vaccination is not currently recommended should be aware of the need to inquire about international travel among Latino children. Health care providers should give the hepatitis A vaccine to child travelers and provide preventive counseling to their parents, to educate them about the risks of transmission and unsafe water and food consumption. ${ }^{14}$

The health status of the Latino population can be assessed accurately through binational cooperation and communication. The Latino population needs an adequate public health infrastructure that addresses the risk of communicable disease. Health has no borders the impact of disproportionate communicable disease rates in Latino children is an issue that needs to be 
addressed by both the United States' and Mexico's public health services.

\section{Acknowledgements}

We acknowledge the assistance of Stanley R. Bissell of the Surveillance and Statistics Section of the Department of Health Services in obtaining the data, and the support of GlaxoSmith Kline.

\section{References}

I. Centers for Disease Control and Prevention. Prevention of hepatitis A through active or passive immunization: recommendations of the Advisory Committee on Immunization Practices (ACIP). MMWR 1999;48(RR-12): I-37.

2. Bell BP, Shapiro CN,Alter MJ, Moyer LA, Judson FN, Mottram K, et al. The diverse patterns of hepatitis A epidemiology in the United States implications for vaccination strategies.J Infect Dis 1998; 178: I579- 1584. 3. Centers for Disease Control and Prevention. Hepatitis surveillance report no. 57. Atlanta: CDC, 2000.

4. Centers for Disease Control and Prevention. Summary of notifiable diseases, United States, 2000. MMWR 2000;49(53): I-17.

5. Atkinson W, Wolfe C, Humiston S, Nelson R, ed. Hepatitis A. In: Epidemiology and Prevention of Vaccine-Preventable Disease. 6th ed. Atlanta: Centers for Disease Control and Prevention, 2000:191-206. 6. Armstrong GL, Bell BP. Hepatitis A virus infection in the United States: model-based estimates and implications for childhood immunization. Pediatrics 2002; 109:839-845.
7. Kemmer NM, Miskovsky EP. Hepatitis A. Infect Dis Clin North Am 2000; I4:605-615.

8. Staes CJ, Schlenker TL, Risk I, Cannon KG, Harris H, Pavia AT et al. Sources of infection among persons with acute hepatitis $A$ and no identified risk factors during a sustained community-wide outbreak. Pediatrics 2000; I06(4):e54.

9. Hepatitis A: special risk for Hispanic populations. Hepatitis Control Report 1996; I (3) Fall, 1996. Online newsletter available at: http:// www.hepatitiscontrolreport.com/vol/v In3I.html. Accessed 05/16/05. 10. California Department of Finance, Demographic Research Unit. Race/ethnic population with age and sex detail, 1970-2040. Sacramento: California Department of Finance, 1998. Available at: http:// www.dof.ca.gov/html/demograp/race.htm. Accessed 07/21/03. I I. Los Angeles County Department of Health Services. Annual morbidity report and special studies report 2002. Los Angeles: Los Angeles County Department of Health Services, 2002:6I-63. 12. United States Census Bureau. 2000 Census of population and housing: public use microdata sample (PUMS). DVD. Washington, D.C.: United States Department of Commerce, Economics and Statistics Administration, 2003.

13. United States Census Bureau. Ranking tables for states: population in 2000 and population change from 1990 to 2000 (PHT-T-2) Table I:

"States ranked by population: 2000." Washington, D.C.: United States Census Bureau, 200I. Available at: http://www.census.gov/population/ www/cen2000/phc-t2.html. Accessed 07/24/03.

14. Weinberg M, Hopkins J, Farrington J, Gresham L, Ginsberg M, Bell BP. Hepatitis A in Hispanic children who live along the United StatesMexico border: the role of international travel and food-borne exposures. Pediatrics 2004; I I4(I):68-73.

15. California Department of Health Services. Communicable disease control in California. Sacramento, CA: Division of Communicable Disease Control, California Department of Health Service, 2000: I-5. 16. Pan American Health Organization. Mortality profiles of the sister communities on the United States-Mexico border.Washington, D.C.: The Organization, 2005:5-6. 